\title{
A delegação de poderes inquisitoriais: o exemplo de Goa através da documentação da Biblioteca Nacional do Rio de Janeiro*
}

\author{
Bruno Feitler**
}

A Biblioteca Nacional do Rio de Janeiro encerra um importante conjunto documental sobre o tribunal da Inquisição de Goa, que permite abordar a história dessa instituição de diversos modos. Aqui, este conjunto será utilizado como base para o estudo do Santo Ofício enquanto instrumento de poder, mais especificamente no que toca aos modos de delegação do poder inquisitorial. O estudo da delegação inquisitorial no Estado da Índia surge aqui, tendo em vista a enorme fragmentação do território de ação do tribunal goês, como o extremo a que chegou o Santo Ofício nesta questão importante, mas pouco estudada, do funcionamento inquisitorial.

Palavras-chave: Inquisição - Goa - Delegação de Poderes

The delegation of inquisitorial powers: Goa in the Documents of the Brazilian National Library, Rio de Janeiro

The Brazilian National Library in Rio de Janeiro holds an important set of documents regarding the Inquisition in Goa. This data allows us to study the history of this institution in many different ways. In the present article, it will be used to unveil

\footnotetext{
"Artigo recebido em fevereiro de 2007 e aprovado para publicação em maio de 2007.

** Professor Adjunto de História Moderna da Universidade Federal de São Paulo (Unifesp). E-mail: feitler@unifesp.br.
} 
the Holy Office as an instrument of power and, more specifically, the modalities of the delegation of inquisitorial power. The study of the delegation of inquisitorial powers in the Estado da Índia, considering its greatly fragmented territory of action, can be regarded as an extreme case of the Holy Office's activities in this important but poorly studied facet of inquisitorial functioning.

Keywords: Inquisition - Goa - Delegation of Powers

La délegation de pouvoirs inquisitoriaux: le cas de Goa d'après les Archives de la Bibliothèque Nationale de Rio de Janeiro

La Bibliothèque Nationale de Rio de Janeiro détient d 'importantes archives sur le tribunal de l'Inquisition de Goa, ce qui permet d'étudier l'histoire de cette institution de plusieurs façons. Dans le texte, ces archives sont étudiées du point de voe du Saint Office en tant qu'instrument de pouvoir, plus spécifiquement en ce qui concerne les formes de délégation du pouvoir inquisitorial. L'étude de la délégation inquisitoriale dans l'Estado da Índia considérant l'énorme fragmentation du territoire sous la juridiction du tribunal de Goa met em relief, les extrêmes auquels est arrivé le Saint Office dans cette question-clé pourtant peu etudiée, du fonctionnement inquisitorial.

Mots-clés: Inquisition - Goa - Délégation de Pouvoirs

Com a abolição definitiva do tribunal da Inquisição de Goa em 1812 (ele havia sido abolido uma primeira vez em 1774 pelo marquês de Pombal e recriado três anos depois por D. Maria), o príncipe regente D. João ordenou que a sua documentação fosse destruída e, ao mesmo tempo, que o promotor da instituição fizesse uma seleção dos documentos "dignos de ser conservados" e os remetesse para a corte no Rio de Janeiro. ${ }^{1}$ É provavelmente esta a documentação que se encontra hoje guardada na seção de manuscritos da Biblioteca Nacional do Rio de Janeiro. Ela é constituída sobretudo pela correspondência enviada aos inquisidores de Goa pelo Conselho Geral a partir de 1567 e foi coligida em 9 códices (MS 25,1,1 a 9) numa ordem cronológica aproximativa. Ainda encontramos nessa documentação um número significativo de decretos, regimentos específicos, editais da fé e éditos particulares

\footnotetext{
${ }^{1}$ Antonio Baião, A Inquisição de Goa, tentativa de história da sua origem, estabelecimento, evolução e extinção (introdução à correspondência dos inquisidores da Índia 1569-1630), vol. I, Lisboa, Academia das Ciências, 1949, p. 415, e Charles Amiel e Anne Lima (estudo, ed. e notas), L'Inquisition de Goa. La relation de Charles Dellon (1687), Paris, Chandeigne, 1997, p. 64-65. Agradeço a Tiago dos Reis Miranda, Giuseppe Marcocci e Ângela Barreto Xavier seus valiosos comentários. Este trabalho foi feito graças a um auxílio à pesquisa da Fundação de Amparo à Pesquisa do Estado de São Paulo.
} 
emitidos pelo inquisidor geral ou pelo Conselho Geral do Santo Ofício, ou ainda alvarás régios, em forma impressa ou em cópia manuscrita. Os quatro primeiros códices foram primorosamente restaurados; os cinco últimos imploram pelo mesmo tratamento.

Seu manuseio foi há pouco facilitado pela indexação (mesmo que imperfeita, visto a natureza da maioria da documentação: cartas que abordam uma infinidade de temas bastante específicos) dos códices, disponível localmente por computador, mas também publicado recentemente em papel nos Anais da Biblioteca Nacional n. 122 (2000). Vale ainda mencionar que pude localizar um "índice das ordens" coligido, aparentemente em 1759, por um "promotor Geraldo [?] do Pilar", mencionado na folha de rosto do volume, que se refere ao conteúdo dos ditos códices, e que também pode funcionar como um instrumento interessante de investigação, pois ele foi sem dúvida uma ferramenta de trabalho para os ministros inquisitoriais, que dele podiam se servir em caso de dúvida sobre como proceder em relação a contendas com a justiça régia ou para buscar mais facilmente os éditos de livros e autores proibidos enviados desde Lisboa. Ele encontra-se assim dividido em categorias que eram úteis aos inquisidores. Este índice, contudo, só enumera sete volumes, com documentação indo até por volta de 1746 (por causa do mau estado do volume, não pude conferir sua data-limite). Neste caso, o tal promotor inquisitorial oitocentista não fez uma seleção de documentos, mas simplesmente enviou ao príncipe regente uma coletânea feita provavelmente pelos sucessivos notários inquisitoriais no decurso do funcionamento do tribunal e finalmente indexado na segunda metade do século XVIII pelo promotor "do Pilar", ${ }^{2}$ adicionando, em dois últimos maços, uma documentação diversa, parecida com aquela dos volumes indexados. Este material formou o atual volume 8, com documentos que vão desde 1615 a 1751, e o volume 9, com documentos posteriores a 1751, atingindo a data-limite de 1807.

Esta variada documentação, apesar de parcial e aparentemente desconexa, oferece muitas possibilidades para se abordar a história da Inquisição. Mas neste texto, vamos estudar a documentação que ilustre ou sirva de base para o estudo do Santo Ofício como instrumento de poder, mais especificamente no que toca aos modos de delegação do poder inquisitorial. O estudo da delegação inquisitorial no Estado da Índia surge aqui, tendo em vista a enorme fragmentação do território de ação do tribunal goês (do Cabo de

\footnotetext{
${ }^{2}$ Biblioteca Nacional do Rio de Janeiro (a partir de agora, BNRJ), MS 48, 14, 8. Ele é composto por c. 95 fols., encadernado em couro, e leva na capa a menção "livro índice das ordens".
} 
Boa Esperança a Timor), como o extremo a que chegou o Santo Ofício nesta questão importante, mas pouco estudada, do funcionamento inquisitorial. Após descrevermos rapidamente como se colocava juridicamente a questão da delegação de poderes, estudaremos, através da documentação do tribunal goês conservado na Biblioteca Nacional do Rio de Janeiro, das fontes éditas e dos estudos disponíveis, como a Inquisição indiana lidou com a imensidão do seu território de ação, que facilmente levou os inquisidores locais e as autoridades de Lisboa a se debruçarem sobre a questão da delegação dos poderes inquisitoriais.

\section{I}

Os poderes da Inquisição portuguesa, segundo a própria bula de fundação do Santo Ofício, a bula Cum ad nil magis de 23 de maio de 1536, eram poderes delegados aos inquisidores gerais pelo papa, que reservava a si a faculdade de absolvição dos casos de heresia. ${ }^{3}$ Os três primeiros inquisidores portugueses, os bispos de Lamego, Coimbra e Ceuta, assim como um quarto personagem a ser escolhido pelo rei D. João III, foram "constituí[dos] e delega[dos] (...) como comissários [do papa Paulo III] e da Sé apostólica e inquisidores" do reino de Portugal e de seus domínios. Esta mesma bula lhes dava permissão para "nomear, subdelegar e deputar" seus poderes, desde que os escolhidos tivessem as qualidades necessárias, ou seja, desde que fossem

pessoas eclesiásticas idôneas, letradas e tementes a Deus (...), mestres em Teologia ou doutores num dos Direitos, ou licenciados ou bacharéis graduados em alguma universidade de Estudo Geral, e tenham atingido pelo menos o trigésimo ano da sua idade, ou cônegos de igrejas catedrais, ou então constituídos em dignidade eclesiástica.

Mas esta delegação, que os inquisidores gerais podiam fazer, e que era evocada no momento da nomeação dos inquisidores de distrito, tinha suas limitações, pois, segundo a bula, os inquisidores gerais tinham "reservadas tais ou tais sentenças como condenações finais e outras que [lhes] parece[ssem], bem como [o poder] de os revocar no todo ou em parte a [seu] arbítrio". ${ }^{4}$ Nada

\footnotetext{
${ }^{3}$ A bula papal in Cona domini, publicada anualmente, descrevia os casos reservados ao papa. As excomunhões da bula da Ceia do Senhor são descritas, por exemplo, em Sebastião Monteiro da Vide, Constituições primeiras do arcebispado da Bahia, São Paulo, Antonio Antunes, 1853 [1.ed., 1719], p. 408-415.

${ }^{4}$ Isaías da Rosa Pereira, "Documentos para a história da Inquisição em Portugal”, Cartório dominicano século XVI, fasc. 18 (1984), p. 23-26.
} 
é dito sobre uma possível "sub-subdelegação" de poderes por parte dos inquisidores de distrito. Contudo, pouco a pouco foi-se colocando o problema desta delegação, tendo em vista a busca por meios de ação mais adaptados à extensão dos tribunais de distrito para além das episódicas visitas inquisitoriais, que, como sabemos, cessaram de agir em 1637.5

O regimento inquisitorial de 1613 instituía que os principais lugares de cada distrito, sobretudo os portos marítimos, deviam ter um comissário inquisitorial e um escrivão para assisti-lo, incluindo a ilha da Madeira, Cabo Verde, São Tomé e "nas capitanias do Brasil" (tít. I, § II). O de 1640 discorre (liv. I, tít. XI) mais longamente sobre os comissários, suas qualidades e obrigações. Os 13 parágrafos do título XI foram retomados tais quais (excetuando-se as primeiras linhas sobre as qualidades requeridas aos candidatos ao posto) no regimento impresso dos comissários, que lhes era fornecido ao mesmo tempo que o certificado de agente inquisitorial. ${ }^{6}$ Os pretendentes deviam, como todo agente ou oficial inquisitorial, ser naturais do "reino", de sangue puro, não terem sido presos pelo Santo Ofício e saber ler e escrever (liv. I, tít. XI, § 1); no caso específico dos comissários, também tinham que ser pessoas eclesiásticas. O regimento dos comissários continua exortando-os à virtude, ao bom exemplo e proibindo-lhes, a eles e aos familiares sob sua jurisdição, de aproveitaremse de sua posição. ${ }^{7}$ Os comissários deviam fazer pessoal e pontualmente as diligências enviadas pelos inquisidores, para assim evitar qualquer erro ou tardança. No caso de inquéritos, eles deviam tomar os testemunhos detalhadamente. Estes testemunhos deviam ser dados na residência do comissário, numa igreja (no caso de a testemunha ser uma "mulher de qualidade") ou na casa da testemunha, em caso de doença. Ao fim de cada relato, o comissário devia escrever de próprio punho, sem comunicar o conteúdo ao escrivão, as qualidades do inquirido e a fé que se devia dar ao seu testemunho, ${ }^{8}$ o que não

\footnotetext{
${ }^{5}$ Sobre a cronologia das visitas inquisitoriais: Francisco Bethencourt, "Inquisição e controle social", História छ̇ crítica [separata], 14 (1987).

6 "Regimento dos comissários do Santo Ofício", in Documentos para a História da Inquisição em Portugal, Cartório Dominicano Português, século XVI, fasc. 18, I. da R. Pereira (ed.), Porto, Arquivo Histórico Dominicano Português, 1984, p. 97-98. Os Regimentos inquisitoriais foram publicados em conjunto por Sônia Siqueira, Revista do Instituto Histórico e Geográfico Brasileiro, n. 392 (julho-set. 1996).

7 "Regimento dos comissários do Santo Ofício", op. cit., p. 97. Daniela Buono Calainho mostra claramente até que ponto alguns familiares inquisitoriais do Brasil faltaram a esta injunção. Agentes da fé. Familiares da Inquisição portuguesa no Brasil colonial, Bauru, EdUSC, 2006, p. $147-165$.

${ }^{8} \mathrm{O}$ regimento de 1640 restringe este procedimento às inquirições de pureza de sangue (liv. I, tít. XI, § 4).
} 
deixava de ser uma intervenção importante no procedimento inquisitorial, servindo o comissário, assim, apesar dos testemunhos transcritos na inquirição, de instância julgadora para os próprios inquisidores. Os comissários deviam vigiar a população do seu distrito e manter os inquisidores informados, por carta, de tudo o que surgisse contra a pureza da fé ou fosse de foro inquisitorial. Em alguns casos (possibilidade de fuga ou importância do caso), eles poderiam enviar um mensageiro, que seria custeado pelo Santo Ofício. Também poderiam ser encarregados da prisão e do controle de pessoas julgadas pela Inquisição que vivessem em sua região de atuação: estrangeiros banidos para o local, habitantes sentenciados ao porte do hábito penitencial ou a atos de penitência regulares. Assim, quanto mais se descia na escala, que ia do papa aos delegados locais do Santo Ofício, passando pelo inquisidor geral e pelos inquisidores de distrito, mais esse poder delegado era restrito, tanto por questões de autoridade, vinculadas às qualidades requeridas para se exercerem essas funções, assim como à vontade de um controle estrito pelas autoridades centrais (inquisidor geral e Conselho Geral) nesta delicada jurisdição que implicava o foro de consciência, quanto pelos poderes de apelo que as instâncias superiores possuíam.

Até as reformas pombalinas, quando a legitimidade inquisitorial reverteu à Coroa, era evocando a autoridade apostólica que os sucessivos inquisidores gerais, ou o Conselho Geral em sua ausência, nomeavam inquisidores e deputados, e era em nome dela que os inquisidores agiam. Contudo, a fixação dos poderes de ministros e oficiais inquisitoriais não se deu de modo imediato, e foram necessários vários acomodamentos no decurso do tempo. Isto se vê tanto no caso dos inquisidores, quanto dos comissários de distrito, que estudaremos mais especificamente adiante.

Durante os primeiros anos de funcionamento do Santo Ofício, a autoridade e autonomia dos inquisidores de distrito não estavam completamente assentadas, sobretudo por questões ligadas à ancestral jurisdição episcopal sobre os casos de heresia, como mostra a evolução da área de atuação tribunal de Lisboa nos anos 1540 e 1550.

A princípio, a área de jurisdição do tribunal, fundado pelo cardeal D. Henrique em 1539, se limitava ao arcebispado de Lisboa. Os casos que surgiam em outras dioceses (excetuando-se na de Évora, onde também havia tribunal) só eram tratados pelos inquisidores lisboetas com autorização expressa do inquisidor geral. Em 30 de junho de 1541 D. Henrique criou 
quatro novos tribunais, em Lamego, Tomar, Coimbra e Porto, mas menos de duas semanas depois, o primeiro inquisidor de Lisboa, João de Melo, ainda recebia por delegação expressa do inquisidor geral autorização para julgar, junto com o bispo do Porto, os feitos de uma mulher, ou "quaisquer outros [casos] semelhantes que vierem para que fordes requerido". ${ }^{9}$ Do mesmo modo, em julho de 1550, os "deputados" da Inquisição de Lisboa (provavelmente os inquisidores) receberam do cardeal infante licença para conhecer certos casos de heresia e apostasia ocorridos especificamente na vila de Ponta do Sol, da ilha da Madeira. ${ }^{10}$ Os quatro tribunais fundados em 1541 foram extintos menos de uma década depois, e o distrito de atuação do tribunal de Lisboa se alargou novamente para todo o Portugal metropolitano (com exceção do arcebispado de Évora) e ilhas, como explicitam duas provisões do cardeal D. Henrique, datadas de 8 de maio de 1551 e de 4 de agosto de $1552 . .^{11}$ Ainda assim, em fevereiro de 1555, Ambrósio Campelo, deputado do tribunal de Lisboa, precisou de uma nomeação expressa de D. Henrique para despachar, com os ordinários das dioceses de Miranda, Porto e Leira, alguns processos pendentes de súditos destes bispados. ${ }^{12}$ Estes casos dos anos 1540 e 1550 , ocorridos fora do arcebispado de Lisboa, parecem apontar para um papel ainda importante e pessoal dos bispos no procedimento inquisitorial, que seria com o tempo cada vez mais atenuado, até que os prelados não fizessem mais que transmitir casos ao Santo Ofício, guardando, porém, uma jurisdição formal sobre os casos de heresia, traduzida finalmente, na grande maioria das vezes, numa licença para que um dos inquisidores julgassem em final em seu nome..$^{13}$

\section{II}

Antes da criação do tribunal inquisitorial de Goa, foi o tribunal eclesiástico local que instaurou os processos por heresia que aí surgiram. Em 1543

\footnotetext{
${ }^{9}$ Isaías da Rosa Pereira, Documentos para a história da Inquisição em Portugal (séc. XVI), Lisboa, Cáritas Portuguesa, 1987, doc. 11.

${ }^{10}$ Antonio Baião, A Inquisição em Portugal e no Brasil. Subsídios para a sua história, Lisboa, Edição do Arquivo Histórico Português, 1920, p. 91 e doc. XLIII.

${ }^{11}$ Isaías da Rosa Pereira, Documentos para a história da Inquisição, op. cit., docs. 2 e 28.

${ }^{12}$ Isaías da Rosa Pereira, Documentos para a história da Inquisição, op. cit., doc. 24.

${ }^{13}$ Ver José Pedro Paiva, "Os bispos e a Inquisição portuguesa (1536-1613)", Lusitania Sacra, 15 (2003), p. 43-76; Giuseppe Marcocci, I custodi dell'ortodossia. Inquizicione e Chiesa nel Portogallo del Cinquecento, Roma, Edizioni di Storia e Letteratura, 2004, p. 155-200; e Bruno Feitler, Nas malhas da consciência: Igreja e Inquisição no Brasil, São Paulo, Alameda/ Phøebus, 2007, p. 158-170. Sobre a área de atuação do tribunal de Lisboa, ver Antonio Baião, A Inquisição em Portugal e no Brasil, op. cit., p. 89-91.
} 
o bispo de Goa, o franciscano D. fr. João Afonso de Albuquerque instaurou um processo de judaísmo contra o bacharel em medicina Jerônimo Dias, para o qual contou com a assessoria do seu vigário geral, de dominicanos e de outros franciscanos, bem como com a anuência do governador Martim Afonso de Sousa, e que resultou na relaxação do réu à justiça secular. No que toca a este papel das ordens regulares, aqui vale lembrar que os jesuítas, grandes instigadores, na pessoa de Francisco Xavier, da fundação do tribunal goês, também participaram ativamente da atividade inquisitorial não só como comissários, conforme veremos, mas também como deputados, junto com membros de outras ordens. ${ }^{14}$

Os processos subseqüentes de que se têm notícia - alguns ocorridos possivelmente em finais de 1546 e outros sem dúvida em 1557 - foram apenas iniciados pelos bispos e/ou vigários gerais de Goa e Cochim e em seguida concluídos pelo tribunal do Santo Ofício de Lisboa, no mesmo momento em que se criava o tribunal indiano (1560) $\cdot{ }^{15}$ Com a consolidação da presença portuguesa em outras regiões do Índico, surgiu o problema da atuação dos inquisidores nesse enorme espaço, que reunia praças fortes e pequenos territórios muito distantes uns dos outros.

Os sucessivos inquisidores gerais aparentemente tentaram contrabalançar os dois problemas que a imensa distância implicava. De um lado, fazia-se necessária uma maior delegação de poderes; daí o papel dado num primeiro tempo aos prelados e em seguida aos comissários, e aparentemente aos familiares, nomeados ambos localmente, ${ }^{16} \mathrm{e}$ daí os comissários terem tido por momentos mais poderes que os do reino. De outro, a distância implicava um controle mais difícil, que abria espaço para exações só passíveis de serem corrigidas depois de um largo espaço de tempo, pois os inquisidores de Goa não recebiam mais que um malote do Conselho Geral por ano.

Num primeiro período, foi com os bispos que os inquisidores contaram para auxiliá-los na perseguição à heresia nos lugares mais distantes de Goa. Assim, um alvará do vice-rei da Índia, datado de abril de 1566, redigido

${ }^{14}$ Ana Cannas da Cunha, A Inquisição no Estado da Índia. Origens (1539-1560), Lisboa, ANTT, 1995, p. 127. Sobre o funcionamento do tribunal: Célia Cristina da Silva Tavares, Jesuitas e inquisidores em Goa: a cristandade insular (1540-1682), Lisboa, Roma Editora, 2004.

${ }^{15}$ Ana Cannas da Cunha, A Inquisição no Estado da Índia, op. cit., p. 151-169.

${ }^{16}$ Pelo menos assim era em 1729, quando o Conselho Geral escreveu aos inquisidores de Goa que "pareceu muito bem a S. Ema a forma que VM referem se pratica na eleição dos comissários que é mui conforme ao que tem ordenado, e só acrescenta que seja também admitido a votar na dita eleição o promotor e seus sucessores, que juntamente são deputados". BNRJ, 25, 1, 7, n. 20. 
provavelmente a pedido dos inquisidores, instava os mestres de naus e navios a auxiliarem o eventual transporte de pessoas presas em nome do Santo Ofício para Goa. Estes presos poderiam lhes ser entregue pelos "bispos de Malaca ou de Cochim, ou seus provisores ou vigários ou administradores de Ormuz ou Moçambique ou quaisquer outros vigários deste arcebispado [que] lhos entregarem para os trazerem à mesa do Santo Ofício da Inquisição". ${ }^{17}$ Não temos informações sobre como este sistema funcionou nos primeiros anos, mas em fins do século ele parece ter fugido ao controle dos inquisidores. Em fevereiro de 1594 o inquisidor geral escrevia aos juízes de Goa sobre notícias que teve de confessores e bispos que absolviam sem comissão inquisitorial. Ele lhes encomendava uma investigação sobre esses casos, para saber se os confessores e prelados tinham permissão papal para tal. Caso contrário, deviam ser repreendidos. ${ }^{18}$ Em novembro do mesmo ano, em carta endereçada ao inquisidor geral o cardeal D. Alberto, os inquisidores responderam explicando os poderes que os prelados da Índia (tanto seculares quanto das ordens regulares) tinham na matéria:

Dos prelados das religiões tomamos a informação que Vossa Alteza manda acerca dos poderes que têm para absolver os apóstatas da terra da excomunhão em que incorrem no foro penitencial, e todos responderam que não tinham, nem eles nem os seus confessores tais poderes, nem tal faziam, tirando o provincial da Companhia de Jesus que diz ter bula para isso de Sua Santidade mas que o seu padre geral lhe tem mandado que não usem dela senão com os neófitos e em caso que não este[ja]m denunciados na mesa do Santo Ofício. ${ }^{19}$ Quanto ao bispo d. fr. André de Cochim governador ao presente deste arcebispado, sabemos de certo que nunca per si absolveu nem mandou absolver de semelhante caso, antes, como deputado que foi desta mesa muitos anos, sabe e confessa que não tem os bispos tais poderes, e todas as vezes que se oferecia alguma necessidade mandava pedir à mesa comissão para os seus vigários poderem absolver da excomunhão da bula da Ceia neste caso; porém, dos bispos de Malaca e China, temos informação que sempre nisto se houveram absolutamente, não somente no foro interior mas também no judicial, até com os portugueses, de que temos já avisado a Vossa Alteza porque a comissão

\footnotetext{
${ }^{17}$ BNRJ, 25, 1, 3, n. 12 .

${ }^{18}$ BNRJ, 25, 1, 3, n. 78.

${ }^{19}$ Inácio de Loyola recebeu oralmente de Paulo III o poder de absolver delitos de heresia no foro da consciência. Esse privilégio foi confirmado pelo papa Julio III por um breve de 1552 . Cf. Giuseppe Marcocci, "Inquisição, jesuítas e cristãos-novos em Portugal no século XVI", Revista de História das Idéias, n. 25 (2004), p. 256-257.
} 
do bispo da China não compreende mais que os da terra e o de Malaca que, é o que mais duro está neste ponto, nem para um nem para outro a tem. ${ }^{20}$

Apesar destas exações, os inquisidores não puderam prescindir da ajuda dos bispos. Em 1605 D. Pedro de Castilho ordenava que se revissem todas as livrarias, tanto de livreiros como de conventos e de particulares. Em Goa o trabalho deveria ser feito pelos revedores do Santo Ofício, enquanto em Malaca e na China os inquisidores deveriam cometer o serviço expressamente aos bispos locais: "e não cometessem diligências a outras pessoas senão aos prelados das dioceses, para não diminuir-lhes a autoridade", o que mostra que a jurisdição inquisitorial naqueles territórios ainda tinha que ser, até certo ponto, negociada. $\mathrm{O}$ inquisidor geral inquire, no entanto, se tal delegação poderia ocasionar algum inconveniente, mostrando também que a confiança nos prelados não era total. Ele ainda pede que os inquisidores lhe façam saber se os bispos cumpriram estas diligências "com o zelo e cuidado que deles se espera". ${ }^{21}$ Esta desconfiança do inquisidor geral nasceu de fatos relatados por seus subordinados de Goa, que parecem ter-lhe escrito sobre a inconveniência de se cometerem os negócios da mesa aos bispos. O inquisidor geral escolheu, no entanto, não prescindir dos seus serviços - ou não desgostar aos prelados, tirando-lhes o que lhes restava de jurisdição em matéria de perseguição à heresia -, mas pediu novamente, em janeiro de 1607, que lhe avisassem se os bispos não fizessem as "diligências como convém". 22

Finalmente, em janeiro de 1610 o inquisidor geral D. Pedro de Castilho sentiu-se confortável para enviar aos inquisidores de Goa cópia do breve Cum audiamus, conseguido por D. Henrique junto ao papa Pio IV em 1561, dandolhe autoridade "para avocar a si as causas de heresia illius [pravi]tatem huius modi sapientes que penderem ante os ordinários, e cometer o conhecimento delas a quem lhe parecer". D. Pedro "confiando (...) de sua virtude, letras e experiência (...) auctoritate apostolica" cometeu aos inquisidores de Goa "suas vezes" em todas as causas pendentes deste tipo. ${ }^{23}$ Este envio (ou reenvio) tardio também mostra que os esforços iniciados pelo cardeal D. Henrique para açambarcar a jurisdição dos casos de heresia ainda não haviam, em 1610,

${ }^{20}$ Antonio Baião, A Inquisição de Goa, correspondência dos inquisidores da Índia (1569-1630), vol. II. Coimbra, Imprensa da Universidade, 1930, p. 215-216. Os bispos em questão, de Malaca e da China (respectivamente D. João Ribeiro Gaio e D. fr. Leonardo de Sá), também são nomeados em BNRJ, 25, 1, 1, n. 186.

${ }^{21}$ BNRJ, 25, 1, 1, n. 4.

${ }^{22}$ BNRJ, 25, 1, 3, n. 87.

${ }^{23}$ BNRJ, 25, 1, 3, n. 111. 
obtido o êxito esperado. ${ }^{24} \mathrm{O}$ envio deste breve crucial para a extensão dos poderes inquisitoriais, e que não tinha razão de não estar também em vigor na Índia desde a sua publicação, demonstra não só que os bispos do Estado da Índia, aproveitando-se da distância, tentaram manter (ou recuperar) sua autonomia no tocante à perseguição aos erros heréticos, ${ }^{25}$ mas também que a Inquisição já estava preparada para prescindir dos seus serviços, delegando sua autoridade a outras instâncias.

E, com efeito, aparentemente, os inquisidores já estavam buscando alternativas, pois em 1609 o bispo de Cochim D. fr. André de Santa Maria reclamava que, apesar de "o ofício da Santa Inquisição [ter-se ordenado] pelos Sumos Pontífices de 400 anos a esta parte para ajudar aos bispos a lançar de seus bispados os que são hereges ou o parecem”, os inquisidores da Índia haviam cometido uma devassa a um frade agostinho, que mais é "um fr. Paulo mestiço que sabe pouco [,]o qual afirmam que foi exposto e enjeitado", sem comunicação com o prelado. Na verdade, os inquisidores se haviam intrometido na luta entre duas facções: o bispo de Angomale, D. Francisco Rodrigues, e os jesuítas de um lado (o agostinho em questão havia sido criado na casa dos padres), e o bispo de Cochim, os franciscanos e o arcediago (de Angomale?) Jorge da Cruz do outro. Queixa-se também fr. André do jesuíta Francisco Soares que "se fez comissário" do Santo Ofício em São Tomé de Meliapor e Negapatão, ambos na costa sudeste da península indiana, território da sua mitra. ${ }^{26} \mathrm{Ou}$ seja, os inquisidores estavam confiando não mais no ordinário (o bispo ou seus vigários), mas em membros de ordens regulares, fossem eles agostinhos ou jesuítas. Em 1613, os bispos estavam reduzidos à condição de

\footnotetext{
${ }^{24}$ Sobre o conteúdo deste importante breve papal e sua aplicação no Reino, ver o texto esclarecedor de Giuseppe Marcocci, I custodi dell'ortodossia, op. cit., p. 97-99 e 164 sq. O breve vem aí transcrito na p. 98.

${ }^{25}$ Em carta de 13 de março de 1610, o inquisidor geral dava razão aos inquisidores, que reclamavam do vigário geral do bispado de Cochim por haver sentenciado portugueses bígamos "sem lhes darem conta do caso nem lhes remeter os autos". Caso o bispo ou seu vigário se recusassem a transmitir-lhes os casos, os inquisidores deviam fazer apelo ao vice-rei. Caso se mostrassem recalcitrantes, deviam lhes mostrar o breve de 1561. BNRJ, 25, 1, 2, n. 68. ${ }^{26}$ BNRJ, 25, 1, 2, n. 83 e 84. "Os padres Damião Gomes, cônego da Sé de Cochim, e Antonio de Carvalho, capelão da Santa Misericórdia, certificamos que indo nós ambos ao convento de S Agostinho com um recado do Sr bispo de Cochim ao prior do dito convento, a sabermos dele por mandado do dito senhor com cuja autoridade ou comissão em seu território e bispado tirava testemunhas ocultamente nos mostrou o dito padre prior uma carta dos srs inquisidores Jorge Ferreira e Gonçalo da Silva dizendo ser dos ditos senhores em que lhe mandavam tirar as testemunhas que os sr bispo da Serra apresentasse e desse. E pelos interrogatórios do dito sr bispo, a qual carta nos leu o dito padre prior e a petição do sr bispo de Cochim, passamos esta em que juramos por nossas ordens ser tudo o acima verdade. Em Cochim em 6 de novembro de $609 . "$
} 
comissários, sem nenhuma autonomia em relação ao procedimento inquisitorial. Em carta de 28 de janeiro daquele ano, o inquisidor geral diz que, caso os inquisidores entendessem que os bispos não fariam os precatórios e diligências a eles enviados de forma satisfatória, os inquisidores podiam cometê-los a outrem "o que melhor o possa fazer". ${ }^{27}$

Contudo, em lugares mais distantes, nomeadamente na China e no Japão, ou também, aparentemente, em Moçambique, tenham sido os bispos, para o extremo-oriente, e o administrador da prelazia, para o território africano, a ocupar oficialmente o cargo de comissário inquisitorial. Uma carta do Conselho Geral de 1628 menciona o uso indevido que era feito pelo padre fr. Antonio do Rosário, governador do bispado da China em ausência do bispo, dos seus poderes "do Santo Ofício, para conservar sua jurisdição ordinária do que se seguiram grandes inconvenientes". ${ }^{28}$ Mas isto não impediu que os cargos continuassem a ser associados: em março de 1650, o rei ordena aos inquisidores de Goa que, caso o governador do bispado de Japão (residente em Macau), fosse pessoa "de tais partes, letras e procedimentos que quando convenha possa ser encarregado de comissário do Santo Ofício por se evitarem (em partes tão remotas) as dúvidas e inconvenientes que se tem seguido de estes cargos andarem divididos", que nomeassem o tal governador comissário. ${ }^{29}$ Em abril de 1677, os inquisidores de Goa receberam uma carta de Lisboa avisando que, se o novo governador do bispado da China, a ser eleito pelo arcebispo de Goa, não tivesse impedimento, a comissaria não fosse desmembrada do tal cargo, mantendo, assim, nas palavras do inquisidor geral, "as ordens do senhor rei d. João IV". ${ }^{30}$ Mas esta regra não foi facilmente aplicada e os inquisidores parecem ter tentado, de tempos em tempos, subverter a ordem joanina, nomeando religiosos (possivelmente jesuítas) como comissários de Macau. Ainda em dezembro de 1696, o bispo de Macau, D. João do Casal, fazia saber ao rei que, contrariamente ao costume da comissaria, que devia "andar anexa ao governador" do bispado, os inquisidores de Goa haviam nomeado religiosos durante certo espaço de tempo. Segundo o bispo, a separação dos cargos fazia com "que facilmente se origina[ssem] preitos com o ordinário sobre jurisdições". Lisboa ordenou que, seguindo a vontade do prelado, o cargo de comissário

\footnotetext{
${ }^{27}$ BNRJ, 25, 1, 2, n. 105.

${ }^{28}$ BNRJ, 25, 1, 3, n. 171. Em fevereiro de 1620, o bispo de Cochim também era chamado pelos inquisidores de Goa de "comissário desta mesa". Antonio Baião, A Inquisiçãa de Goa, correspondência dos inquisidores da Índia, op. cit., p. 568.

${ }^{29}$ BNRJ, 25, 1, 4, n. 153.

${ }^{30}$ BNRJ, 25, 1, 6, n. 195.
} 
fosse passado "a uma das três dignidades do dito bispado", mantendo mais uma vez o costume fixado em 1650 pelo soberano, apesar da subdelegação do cargo a um cônego. ${ }^{31}$ Ainda em 1707 era o provincial jesuíta da província do Japão, Francisco Pinto, o comissário em Macau e seu distrito. Os atritos, entretanto, continuavam, pois o padre Pinto havia então sido excomungado pelo patriarca da Antióquia, Charles Thomas de Maillard de Tournon, que, é bem verdade, também se desentendeu com o bispo. ${ }^{32}$ Dez anos mais tarde foi a vez de o bispo D. João do Casal ser rogado para não deixar o cargo de comissário de Macau. Caso contrário, os inquisidores deveriam nomear um jesuíta, com exceção, evidentemente, do padre Pinto. ${ }^{33}$

A dissociação da comissaria da pessoa do prelado continuou a causar problemas, pois em 1729 houve uma contenda entre o vigário geral de Macau e o comissário local, o cônego e rico mercador Manoel de Queirós Pereira, que invocou o foro inquisitorial para fugir da sentença lançada contra ele pelo vigário geral num litígio sobre heranças. ${ }^{34}$ Após lançarem-se excomunhões mútuas, pelo fato de o comissário fazer-se “juiz em causa própria” em vez de apelar aos inquisidores, o vigário chegou a ser sentenciado pelos inquisidores (com demasiado rigor, segundo o Conselho Geral), apesar de ter-se apresentado à mesa de Goa. ${ }^{35}$ É ainda a este cônego que se refere Lisboa em 1734, ao escrever que "o comissário de Macau, chamado Manoel de Queirós Pereira, é indigno do cargo e muito prejudicial ao Santo Ofício pelo seu escandaloso procedimento". Os inquisidores deviam tirar "uma exata informação" sobre este caso - que infelizmente não é descrito na carta que estes receberam do Conselho Geral - e, confirmando-se o que se dizia do comissário, que fosse suspenso e substituído por outra pessoa. O Conselho Geral aproveita para

${ }^{31}$ BNRJ, 25, 1, 5, n. 72.

${ }^{32}$ BNRJ, 25, 1, 8, n. 219. O patriarca de Antióquia havia sido nomeado visitador apostólico e legado a latere na Índia e na China por Clemente XI por breve de 4 de junho de 1702 . Foi ele o grande instigador da querela dos ritos. Cf. p. Manuel Teixeira, Macau no séc. XVIII, Macau: Imprensa Nacional de Macau, 1984, p. 26, 33-34 e passim.

${ }^{33}$ BNRJ, 25, 1, 5, n. 241.

${ }^{34}$ Cônego da Sé de Macau, foi nomeado arcediago em fevereiro de 1708, passando mais tarde a tesoureiro-mor. Era o mais rico de todos os cônegos. Tendo nascido de uma tradicional família de mercadores de Macau, possuía barcos e exercia ele próprio a mercancia. Ao ser nomeado comissário do Santo Ofício, fez com que sua provisão fosse lida dos púlpitos das igrejas. Ele invocou os privilégios dos oficiais da Inquisição para escapar de uma excomunhão lançada pelo vigário geral do bispado em decorrência dos litígios que surgiram sobre a herança de parentes seus entre ele e Francisco Xavier Doutel, também comerciante e ministro régio local. Cf. p. Manuel Teixeira, Macau e sua diocese, Macau, Tipografia da Missão do Padroado, 1967, vol. VII, p. 348-357.

${ }^{35}$ BNRJ, 25, 1, 7, n. 21. 
chamar a atenção aos inquisidores para que não dissimulassem "excessos de algum em particulares que podem pertencer ao reto ministério do Santo Ofício". ${ }^{36}$ Estes três últimos casos mostram o quão corporativamente os inquisidores de Goa agiam em relação aos seus subordinados, causando espécie até ao Conselho Geral. Este corporativismo inquisitorial valia também, como veremos adiante, para os oficiais mais subalternos do tribunal indiano.

Quanto à prelazia de Moçambique, uma carta do inquisidor geral D. Francisco de Castro, de maio de 1639, dá a entender que, uma vez provido pelo rei o administrador eclesiástico daquele território, o próprio D. Francisco o nomearia, ainda em Lisboa, comissário, "pois tudo [leva a] crer que será pessoa capaz para esta ocupação". ${ }^{37}$ Contudo, em 1728, como para Macau, os dois cargos também estavam dissociados. Em carta enviada aos inquisidores de Goa, o Conselho Geral menciona ao mesmo tempo uma denúncia feita contra "o padre mestre deputado fr. Manoel de Santo Tomás e administrador episcopal dos rios de Sena e Moçambique" e o comissário do Santo Ofício em Moçambique, o dominicano padre fr. Francisco de Nossa Senhora. ${ }^{38}$

\section{III}

Esta transferência da delegação de poderes inquisitoriais dos prelados a comissários (frades ou jesuítas missionários) se deu pouco a pouco, em grande parte pela dificuldade de controle sobre as atividades desses comissários. A correspondência inquisitorial faz menção de comissários do Santo Ofício no Estado da Índia já no século XVI, sem que se possa, contudo, dizer ao certo se se tratavam de comissários oficialmente nomeados, como ocorrerá mais tarde, ou simplesmente de pessoas a quem os inquisidores deviam encomendar inquirições ou delegar poderes pontualmente. Esta existência de comissários locais já no século XVI (tanto na Índia quanto no Reino) deve ser confirmada através de outros documentos, pois eles aparecem apenas teoricamente, na vontade dos inquisidores gerais D. Jorge de Almeida, por volta de 1585, e do cardeal arquiduque D. Alberto, um par de anos mais tarde, e relacionados, no que toca ao além-mar, a perdões concedidos a "pessoas que se lançaram com os mouros e gentios" que se apresentassem aos inquisidores de Goa "ou seus

\footnotetext{
${ }^{36}$ BNRJ, 25, 1, 7, n. 45.

${ }^{37}$ BNRJ, 25, 1, 4, n. 66.

${ }^{38}$ BNRJ, 25, 1, 7, n. 18.
} 
comissários que nomearem nas fortalezas e lugares distantes da dita cidade". ${ }^{39}$ Poucos anos antes, o cardeal D. Henrique, enquanto rei, havia emitido alvarás de teor semelhante para os territórios do norte da África, mas enviados não aos inquisidores ou seus "comissários", mas diretamente aos "provisores e vigários gerais dos lugares de África". ${ }^{40}$

Uma carta dos inquisidores de Goa datada de 30 de agosto de 1594 faz referência a um "comissário do Santo Ofício" em Baçaim, ${ }^{41}$ mas estes representantes locais da Inquisição são mais especificamente nomeados na primeira década do século seguinte, mesmo que não possamos saber se esses comissários estariam ligados aos ordinários ou ao clero missionário local. Em 1607, o inquisidor geral D. Pedro de Castilho, escandalizado, ordena que

\footnotetext{
${ }^{39}$ Eis o teor do edital de D. Alberto: "O Cardeal Arquiduque (...) e porquanto nossa tenção é favorecer as pessoas que tendo cometido erros contra Nossa Santa Fé Católica se querem apartar deles e ajuntar seus bons propósitos para remédio e salvação de suas almas, pela presente havemos por bem de lhes conceder este édito da graça e perdão geral pelo qual vos cometemos autoridade apostólica nossas vezes e damos poder para que vindo-se quaisquer das ditas pessoas que se lançaram com os Mouros e gentios apresentar ante vós ou ante vossos comissários que para isso nomeados nos lugares distantes dessa cidade de Goa dentro no tempo e termo que por vós lhe for limitado que será o que vos parecer, conformado-vos com a necessidade que disso houver. E com a distância dos lugares em que as ditas pessoas podem estar e fazendo elas inteira e verdadeira confissão de suas culpas que contra NSF tiverem cometido por mais graves e enormes que sejam os possais receber e recebais com muita caridade e (...) Lisboa aos (...) de março de 1588 [?] O Cardeal”. BNRJ, 25, 1, 3, n. 58. O alvará régio perdoando a confiscação dos bens das pessoas nestes casos, emitido a pedido de D. Jorge: BNRJ, 25, 1, 3, n. 59. Sobre os projetos de criação de uma rede de comissários no Reino, ver Bruno Feitler. Nas malhas da consciência, op. cit., p. 88-89, e Giuseppe Marcocci, I custodi dell'ortodossia, op. cit., p. 346-349.

40 "Aos prouisores e Vigarios gerais dos lugares de Africa a que esta minha carta for mostrada como são informados que muitas pessoas nessas ditas partes sendo christãos e tendo professado a ley euangelica estando em terras de mouros, captivos, ou lançãdose com eles por homizios ou por outras causas (...) se fazem mouros e judeus (...) Mando a uos ditos prouisores e Vigários gerais dos ditos lugares de Africa que vindo a eles daqui em diante ter as ditas pessoas (não sendo porem da nação dos christãos novos) e pidindo uos remedio para o peccado que cometeram em se apartar da fee os Recebais com muita charidade e os absoluais ad reincidenciam da excomunhão em que emcorreram apartando se da nossa santa fee catholica, e os mandeis confessar a seus confessores, pormetendo eles primeiro ante uos de se apartar de seus erros inteiramente (...) outro si prometerão uir apresentar se na Inquisição desta cidade de lisboa ante os Inquisidores dela dentro no tempo que lhes asinardes para isso que serra o que uos parecer (...) e ao tempo que lhes fizerdes a dita notificação lhes certificareis da minha parte que seram tratados com muita benignidade e misericordia, e que lhe nam sera lançado habito pinitencial por mais graues culpas que aiam cometido (...) e para mais os asegurardes lhes mostrareis outra minha prouisão que com esta uos sera dada, pela qual como Rey lhes perdoo e remito todas as penas postas pelas leis e ordenações de meus Reinos." (9 de fevereiro de 1579), António Baião, "A Inquisição em Portugal e no Brazil", Archivo Historico Portuguez, vol. V (1907), p. 424-425.

${ }^{41}$ Antonio Baião, A Inquisição de Goa, correspondência dos inquisidores da Índia, op. cit., p. 208.
} 
os "comissários do Santo Ofício da Inquisição em Maluco, China, Malaca, Moçambique e outras partes" não tenham mais os poderes que os inquisidores pareciam terem-lhes delegado, o que lhes permitiu ter "tribunais formados do Santo Ofício" localmente. Lisboa lembra que os comissários não podiam fazer mais que tomar as denúncias e efetuar as devassas ordenadas pela mesa. Prisões, somente em caso de perigo eminente de fuga. ${ }^{42}$ Poucos anos depois (1613), a pedido do papa, o mesmo inquisidor geral concede licença por cinco anos para que dois dominicanos missionários em Solor (pequena ilha ao norte de Timor), escolhidos pelos inquisidores, pudessem absolver os "novamente convertidos" no foro da consciência "pela grande distância que daquela partes há a essa cidade de Goa". ${ }^{4}$

Os poderes e as qualidades dos comissários da Índia são mais especificamente definidos por Lisboa em 1621, quando o inquisidor geral D. Fernão Martins Mascarenhas, respondendo a dúvidas da mesa indiana, define que os comissários

poderão fazer as diligências de defesas e contraditas, perguntar e ratificar testemunhas, para o que os inquisidores lhes darão larga instrução. E nas partes muito remotas poderão tomar confissões dos apresentados e conhecer dos casos leves quando o feito for tal que, confessado, ou plenamente provado, não possa chegar a mais que [a uma abjuração] de leve suspeita, o poderá despachar chamando por adjuntos até três ou quatro religiosos da Companhia ou de outras religiões, pessoas doutas e que tenham as partes necessárias, chamando também o ordinário.

Esta presença, ou procuração, era necessária para se lavrarem sentenças. O inquisidor geral ordenava que, caso possível, se enviasse o processo aos inquisidores antes de se dar execução à sentença e que "outros casos que passarem de levi sem o comunicarem com os inquisidores dando-lhe deles larga relação, e eles avisarão do que se deve fazer". Os inquisidores deviam fazer "comissários nos lugares que lhes parecer serem necessários, a pessoas doutas, e que tenham as partes que convém a tal ministério". ${ }^{4}$

Mas em 1632, o inquisidor geral seguinte, D. Francisco de Castro, volta atrás, ordenando que os comissários, "ainda que estejam em partes remotas, não poderão fazer mais negócios que os que desta Inquisição se lhe cometerem”, retirando inclusive aos inquisidores o poder de nomear deputados e familiares,

${ }^{42}$ BNRJ, 25, 1, 2, n. 30.

${ }^{43}$ BNRJ, 25, 1, 8, n. 157.

${ }^{44}$ BNRJ, 25, 1, 3, n. 204. 
sem dúvida pela "exorbitância" ou o "escândalo que há do procedimento de alguns" desses últimos, e de alguns comissários. ${ }^{45}$ Uma carta de 1636 menciona novamente a nomeação de familiares pelos inquisidores locais. ${ }^{46}$ Os excessos de alguns comissários, um fr. Luiz Fragoso, e do comissário de Baçaim, que não é nomeado, renderam protestos junto à Congregação romana do Santo Ofício para o primeiro, e junto ao Conselho Ultramarino para o segundo, fazendo com que em 1672 Lisboa ordenasse que os dois fossem suspensos e os demais fossem lembrados de que "não têm jurisdição alguma", ${ }^{47}$ equiparando assim os comissários do Estado da Índia com os do Brasil, do reino de Angola e também da metrópole. ${ }^{48}$

Dezoito anos depois, um documento interno ao tribunal goês (uma "instrução e regimento para os comissários do Santo Ofício" dos "territórios do Norte" que aparentemente acompanhava o "genérico" regimento impresso) delega novamente sua jurisdição em casos específicos. "A gente da terra pobres e cativos, absolverá sacramentalmente" do foro interior e também no exterior caso não contivessem "blasfêmias hereticais e superstições e gentilidades sem sacrifício ou oferta, adoração sumbaia ou salema ou qualquer outras cerimônia demonstrativa e protestativa de alguma seita". Quanto às pessoas ricas, podiam absolvê-las nos casos leves do foro interior. ${ }^{49}$ Este documento de 1690 é o último que até agora encontrei que retomasse a questão dos poderes delegados aos comissários. Outras investigações poderão confirmar se este momento fixou os poderes comissariais do Estado da Índia.

\section{VI}

Vimos que foi por volta de 1690 que se fixaram os poderes dos comissários do tribunal goês. É justamente no extremo fím do século XVII que começa a surgir na documentação da Biblioteca Nacional um agente inquisitorial específico do Estado da Índia, uma espécie de substituto nativo do

\footnotetext{
${ }^{45}$ BNRJ, 25, 1, 4, n. 9 e 25, 1, 4, n. 20.

${ }^{46}$ BNRJ, 25, 1, 4, n. 40.

${ }^{47}$ BNRJ, 25, 1, 6, n. 142 e n. 177.

${ }^{48}$ Sobre os comissários do Atlântico, ver Bruno Feitler. Nas malhas da consciência, op. cit., p. 88-93 e passim.

${ }^{49}$ BNRJ, 25, 1, 8, n. 226.
} 
familiar branco ${ }^{50}$ que servia de intérprete ${ }^{51}$ aos inquisidores, ao juiz do fisco e aos comissários, fazia inquirições e também gozava dos privilégios de ofício: o naique.

Os muito reverendos padres comissários poderão fazer eleição de naiques e notários que lhe houverem de assistir no serviço do Santo Ofício. Os naiques para fazerem as diligências de fora pertencentes a ele, e servirem de língua, e os notários para escreverem os negócios do Santo Ofício (...) e as tais pessoas assim naiques como notários terão as qualidades necessárias do que houverem de servir no Santo Ofício que é serem sem nota alguma na limpeza de seu sangue e em seu procedimento em todas as matérias e que não tenham padecido alguma infâmia publica pelas justiças nem fossem penitenciados ou presos pelo Santo Ofício, por que do contrário resultam muitos inconvenientes ao decoro e respeito que se deve ao tribunal e seus ministros. ${ }^{52}$

$\mathrm{O}$ mais interessante era que se esperava desses naiques, ${ }^{53}$ assim como dos comissários, que supervisionassem os comportamentos dos nativos cristãos da sua região de atuação, ${ }^{54}$ podendo os comissários sancionar com "alguma penitência moderada que não pareça vingativa ou rigorosa" os que se vestissem ou portassem barba ao modo gentílico. Também encomendava-se que os comissários prendessem, castigassem ou expulsassem iogues, faquires ou brâmanes, que circulavam em busca de esmolas e ensinavam aos gentios e mouros "os dogmas falsos de suas seitas". ${ }^{55}$ Assim, os comissários dos territórios do norte (não há menção do que ficou resolvido em relação aos comissários

50 "Servem com toda a fidelidade para todo o ma[is] ministério em que o Santo Ofício os ocupa na falta de familiares brancos [1724]", BNRJ, 25, 1, 5, n. 215. Esta é a única menção, junto com outra citada abaixo de um Canarim, da extração racial dos naiques.

${ }^{51}$ Antes do século XVIII, esse papel de intérprete pode ter sido ocupado por jesuítas. Era pelo menos isso que esperava o inquisidor geral em começos do século anterior: "quanto o língua que pedem para servir de intérprete dos presos, parece que se devem ajudar dos padres da Companhia entre os quais há pessoas que sabem as línguas e com eles se fará o negócio com mais segredo", BNRJ, 25, 1, 3, n. 87.

${ }^{52}$ Documento redigido em 1702 pelo inquisidor Manoel Nunes Viana, visitador das fortalezas do norte para os comissários locais, BNRJ, 25, 1, 5, n. 132.

${ }^{53}$ No Estado da Índia quase todas as instituições tinham seus naiques, que eram um tipo de oficial de diligências ao mesmo tempo em que, dependendo do caso, podia servir de intérprete. O mesmo termo foi utilizado para designar o "cabo ou chefe dos soldados indígenas de infantaria”. Cf. Sebastião Rodolfo Dalgado, Glossário Luso-asiático, Hamburgo, Helmut Buske Verlag, 1982, vol. 2, p. 91-92; Vitorino Magalhães Godinho, Les finances de l'Etat portugais des Indes Orientales (1517-1635), Paris, Fundação Calouste Gulbenkian, 1982.

54 “Têm demais [os naiques] obrigação vigiarem a que se não façam pagodes nem venham gentios a ensinar nem exercer seus depravados ritos e perverter aos vassalos de Vossa Majestade [1714]", BNRJ, 25, 1, 5, n. 215.

${ }_{55}$ BNRJ, 25, 1, 3, n. 204. 
dos territórios mais longínquos, como Moçambique ou Macau) mantiveram um certo poder delegado dos inquisidores, podendo, inclusive, nomear naiques. ${ }^{56}$ Mas a partir de então os comissários em geral, sobretudo aqueles dos territórios densamente povoados por indianos convertidos como Salcete e Bardês, próximos da cidade de Goa, parecem ter sido incumbidos, bem como seus subordinados, os naiques, da supervisão do bom comportamento dos neófitos. Do mesmo modo, o comissário de Moçambique, fr. Francisco de Nossa Senhora, escreveu por volta de 1725 ao inquisidor geral, por via dos inquisidores de Goa, para que ele interviesse no sentido de se remediar o prejuízo que localmente "causa à cristandade o mouro Baxirá Mocally". Aparentemente a autoridade do comissário não era suficiente para aquietar o rico comerciante muçulmano. ${ }^{57}$ Confirmando-se a efetividade deste papel, esta informação reforça a tese defendida por Célia Tavares de que a Inquisição de Goa foi um "poderoso instrumento no processo de 'ocidentalização' da sociedade", ${ }^{8}$ sempre no registro negativo da fiscalização, em contraponto ao registro positivo da evangelização (que teoricamente implicava um consentimento dos conversos), mesmo que a afiliação missionária dos comissários do tribunal de Goa possa matizar um pouco esse caráter policialesco aqui posto em relevo. Por outro lado, a importância numérica dos naiques, restritos por pressão régia em 1728 a 12 privilegiados para Goa, 30 para Salcete e 15 para Bardês, ${ }^{59}$ mostra que os cristãos locais se apoderaram rapidamente deste instrumento de ascensão social, que lhes associava a uma instituição de peso do mundo português e lhes permitia gozar de privilégios. O papel de "polícia de costumes" que lhes foi outorgado junto aos comissários serviu sem dúvida para realçar seu papel no seio da população local. Pouco mais de um ano antes, em 1726, Lisboa ordena que se nomeiem preferencialmente homens velhos para a função, "que já pelos anos sejam escusos da milícia" a que alguns naiques tentaram, aparentemente, se subtrair, o que aponta mais uma vez para o uso das funções inquisitoriais como instrumento de distinção social, como bem o mostrou José Veiga Torres ${ }^{60}$ para o caso dos familiares, que também se verifica

\footnotetext{
${ }^{56}$ BNRJ, 25, 1, 5, n. 132.

${ }^{57}$ BNRJ, 25, 1, 7, n. 4.

${ }^{58}$ Célia Cristina da Silva Tavares, Jesuitas e inquisidores em Goa, op. cit.

${ }^{59}$ BNRJ, 25, 1, 7, n. 18.

${ }^{60} \mathrm{BNRJ}, 25,1,5$, n. 220. Também havia naiques em Macau e Moçambique, mas não encontrei informações sobre seu número. José Veiga Torres, Da repressão religiosa para a promoção social. A Inquisição como instância legitimadora da promoção social da burguesia mercantil, "Revista Crítica de Ciências Sociais”, n. 40 (1994), p. 109-135.
} 
em relação aos familiares de Goa tão cedo quanto $1609 .{ }^{11}$ A prova de que isto ocorreu são os conflitos em que os naiques surgem como protagonistas.

Em 1714 subiu ao parecer do monarca um conflito de jurisdição criminal entre os inquisidores e o ouvidor geral do crime de Goa. Algum tempo antes, o naique Manoel Colaço, morador na fortaleza de Rachol, nas terras de Salcete, "por desavenças" que teve, deu umas pancadas em dois irmãos "dos naturais da terra" chamados Manoel e Paulo, criados do contratador dos direitos dos coqueiros, Antonio João de Albuquerque Gancar. O capitão da fortaleza chegou a fazer auto de querela sumário, mas o vice-rei D. Rodrigo da Costa, a pedido do naique, deferiu-o ao Santo Ofício. A causa continuou, entretanto, no mesmo tribunal, pois o ouvidor geral Miguel Monteiro Bravo recusou-se a acatar os precatórios dos inquisidores, afirmando ser sua a jurisdição, pelo fato de o réu ser oficial privilegiado. O rei decidiu em favor da Inquisição. ${ }^{62}$

Mais de 15 anos antes, por volta de 1696, um soldado de cavalo da tropa de Salcete deu "uns pescoções" em um Canarim naique do fisco, sendo em seguida preso pelos inquisidores, esquecendo-se estes que o soldado, por ser militar, também tinha foro privilegiado. Depois de uma troca de presos (o vicerei havia mandado prender o naique a ferros), o soldado foi preso pelo vice-rei, perdendo também sua patente de cabo de esquadra. ${ }^{63}$ Nos dois casos o Santo Ofício preservou os privilégios e a honra de seus oficiais laicos, alçando-os assim acima dos outros cristãos locais.

Esta honra era difícil de se conquistar, e mesmo os inquisidores estavam sujeitos a afrontas dos potentados locais. Pedro Vaz de Siqueira, fidalgo morador de Macau, estava jurado para casar com D. Maria de Noronha. Mas sabendo ele que no mesmo momento se tratava o casamento de uma irmã dela com um irmão do inquisidor Francisco Delgado de Matos (inquisidor de Goa entre 1666 e 1676), disse que se esse segundo casamento se efetuasse, ele não casaria mais com sua prometida, "por não ser aquele [inquisidor] fidalgo da sua qualidade". ${ }^{64} \mathrm{O}$ Conselho Geral ordenou que o comissário de Macau

${ }^{61}$ Escreve então o inquisidor geral: "e por termos informações que os familiares da Inquisição os mais deles são chatis ou soldados, e que não servem o Santo Ofício se não por respeito de se valerem dos privilégios em seus tratos, os inquisidores sejam advertidos não aceitem familiares homens desta condição e procurem eleger pessoas que possam bem servir o Santo Ofício com a quietação e autoridade que convém”, BNRJ, 25, 1, 2, n. 69.

${ }^{62}$ BNRJ, 25, 1, 5, n. 215.

${ }^{63}$ BNRJ, 25, 1, 5, n. 80. Os inquisidores também haviam prendido um certo Manoel Duarte por haver morto um familiar do Santo Ofício enquanto este não estava exercendo suas funções. $\mathrm{O}$ inquisidor geral estranha os fatos e pede conta aos inquisidores de Goa.

${ }^{64}$ BNRJ, 25, 1, 6, n. 208. 
chamasse o fidalgo à sua presença, tendo consigo seu escrivão, e o "advertisse do respeito que se deve às pessoas que na Índia ocupam o lugar de inquisidor”. O comissário local, um agostinho, parece que se excedeu, repreendendo-o em público na igreja do seu convento, dizendo até em seguida que "ficara com a mão folgada do que havia feito". O Conselho ordenou que, caso o procedimento excessivo tivesse sido iniciativa do comissário (e não dos inquisidores), ele fosse repreendido e o fidalgo desagravado. Este pequeno episódio demonstra a importância que tinha o estrato social para os inquisidores de Goa, e que eles também entravam, através de seus irmãos e irmãs, e sem dúvida tios, primos e sobrinhos (e aparentemente a contragosto de alguns), nas alianças das famílias das regiões em que viviam. ${ }^{65}$

Vimos que no Estado da Índia, tendo em vista o imenso espaço sobre o qual o tribunal inquisitorial exercia sua jurisdição, os representantes locais do Santo Ofício tiveram, dependendo da época, poderes delegados bastante alargados. Vimos também que houve um primeiro período de experimentação, em que o Santo Ofício tentou servir-se da rede eclesiástica secular para dar cabo da missão inquisitorial. Isto se deveu não só ao fato de a Inquisição não ter, na segunda metade do século XVI, nenhuma outra experiência no tocante a essa delegação de poderes, mas também porque este foi o modo encontrado pela instituição para incluir os bispos locais nos procedimentos inquisitoriais, evitando, assim, pensava Lisboa, que os mesmos tentassem avocar a si uma jurisdição que tradicionalmente havia sido exclusivamente sua. Mas assim não se passou, e primeiro os inquisidores de Goa, e em seguida o próprio inquisidor geral, escolheram confiar em comissários especificamente nomeados para servir ao Santo Ofício. Além disso, é interessante notar que as necessidades locais fizeram com que a rede de familiares e de comissários do tribunal goês já estivesse constituída em começos do século XVII, momento em que são nomeados os primeiros comissários do mundo atlântico português, inclusive no Portugal metropolitano. Diferentemente do que acontecia no resto do mundo português (quando eram nomeados pelo inquisidor geral), segundo esta documentação, os comissários da Índia parecem ter sido escolhidos e nomeados pelos inquisidores de Goa, sobretudo entre os membros de ordens religiosas, como na África ocidental, o que marca outra diferença com a Inquisição em Portugal e no Brasil, onde os comissários foram preferencialmente

\footnotetext{
${ }^{65}$ Para um estudo de fundo sobre importância social da malha inquisitorial como um todo, dos familiares aos inquisidores, ver Jaime Contreras, El Santo Ofício de la inquisición de Galícia (poder, sociedad y cultura), Madrid, Akal, 1982.
} 
padres seculares: África e Ásia permaneceram então as terras de missão por excelência, onde os autóctones, uma vez convertidos, entravam sob a jurisdição inquisitorial e onde os membros das ordens regulares em missão eram muitas vezes os únicos padres da região. ${ }^{66}$ Mas este quadro, em que o clero regular dominava os postos de comissários, não se deu, como vimos, desde a fundação do tribunal goês.

As condições locais também fizeram com que surgisse na Índia um oficial inquisitorial específico ao seu mundo, e dele saído: o naique, que, além de servir de intérprete - que parece ter sido a sua função primeira -, também acabou por ter um papel de controle da população local, assimilando ao mesmo tempo o importante capital social que a função inquisitorial outorgava.

Finalmente, vale frisar que este estudo, feito somente a partir da documentação guardada na Biblioteca Nacional do Rio de Janeiro (para além das fontes impressas e da bibliografia), objetivou ter uma idéia geral de como os poderes inquisitoriais se diluíram nas condições extremas desse laboratório de instituições que foi o oriente português, assim como pôr em relevo esta mesma documentação, que me parece conter um farto material para se compreender como funcionou a Inquisição.

${ }^{66}$ Sobre os comissários inquisitoriais: José Veiga Torres, Da repressão religiosa para a promoçãosocial. A Inquisição como instância legitimadora da promoção social da burguesia mercantil, Revista Crítica de Ciências Sociais, n. 40 (1994), p. 109-135; James Wadsworth, Agents ofOrthodoxy: Honor, Status, and the Inquisition in Colonial Pernambuco, Brazil, Boulder (CO), Rowman \& Littlefield, 2006; e Bruno Feitler, Nas malhas da consciência, op. cit. 